\title{
5-6 yaş çocuklarına sayı kavramını kazandırmada drama çalışmalarının etkisinin incelenmesi ${ }^{*}$
}

\section{Investigating the effect of drama studies on gain the concept of number for 5-6 year old children}

\section{Makalale Geçmişi \\ Geliş : 25 Ocak 2018 \\ Düzeltme : 03 Mart 2018 \\ Kabul : : 17 Nisan 2018}

Makale Türü

Özgün Makale
Article History

Received : 25 January 2018

Revised : 03 March 2018

Accepted : 17 April 2018

Article Type

Original Article

\author{
Elif Demir ${ }^{1}$, Hale Dere Çiftçi ${ }^{2}$
}

Öz: Erken çocukluk dönemi, gözle görülür değişimlerin yaşandığı ve çocuğun yaşamının temellerini oluşturan matematiksel kavramları öğrenmeye başladığı dönemdir. 5-6 yaşlarındaki çocuklar matematiksel beceri ve kavramların gelişiminde aktif öğrenmelerini sağlayan ortamlara ve kullanabilecekleri yöntemlere gereksinim duymaktadırlar. Bu yöntemlerden biri olan drama, çocukların matematiksel kavramları yaparak, yaşayarak ve eğlenerek öğrenmelerini kolaylaşmaktadır. Yarı deneysel yöntem kullanılan bu çalışmada, 5-6 yaş çocuklarına sayı kavram becerilerinin kazandırılmasında drama çalışmalarının etkisi incelenmiştir. Tesadüfi yöntemle belirlenen iki okul öncesi eğitim kurumundan çalışmaya katılmayı kabul eden toplam 60 çocuğun aileleri ile veli görüşmeleri yapılarak çalışma hakkında bilgi verilmiştir. Ailelere "Kişisel Bilgi Formu”, çocuklara ise '5-6 Yaş Çocuklar İçin Sayı ve İşlem Kavramları Testi’ uygulanmıştır. Ön test sonucunda yaş grubuna göre ortalamanın altında puan alan çocuklar seçilerek, tesadüfi yöntemle her bir eğitim kurumundan on beş deney, on beş kontrol olmak üzere otuz kişilik deney ve kontrol grubu oluşturulmuştur. Uzman görüşleri alınarak sayı ve işlem kavramlarının gelişimine yönelik hazırlanan drama planları, 15'er kişilik iki deney grubuna da altı hafta süreyle, haftada iki gün iki saat olarak uygulanmış, sonrasında deney ve kontrol gruplarına son testler uygulanmıştır. Araştırmanın sonucunda, 5-6 yaşa uygulanan yaratıcı drama eğitiminin çocuklara matematiksel becerileri ve sayı kavramlarını kazandırmada etkili olduğu tespit edilmiştir.

Anahtar Kelimeler: Sayı Kavramı, drama, okul öncesi dönem çocukları, sayı becerileri, drama eğitimi

Abstract: In the study using the experimental method, the effect of drama studies in the acquisition of number concept skills such as rhythmic counting, addition, subtraction, matching, and missing number symbol for 5-6 year old children was examinedInformation was provided on the content and scope of the study by parents' meetings with a total of 60 children in two pre-primary education institutions determined by random methods. "Personal Information Form" was applied to the families who accepted to participate in the study and "Number and Process Concept Tests for Children 5-6 years old" were applied to the children. At the end of the pre-test, children who score below the average according to the age group were selected, fifteen of them experimental and fifteen of them controls, were created randomly. Experiment was studied in two nursery, sixty children completed the thirty control group. As a result of the research, it was determined that creative drama education applied at 5-6 years is effective in giving mathematical skills and number concepts to children.

Keywords: Number Concept, drama, pre-school children, number skills, drama education

\footnotetext{
Başlıca Yazar: Elif Demir

* 5.Uluslararası Okul Öncesi Eğitim Kongresinde “sözlü bildiri” olarak sunulmuştur.

${ }^{1}$ Ankara Yıldırım Beyazıt Üniversitesi, Sağlık Bilimleri Enstitüsü, Çocuk Gelişimi ve Eğitimi Bölümü, e.elfdemir85@gmail.com

${ }^{2}$ İstinye Üniversitesi, Sağlık Bilimleri Fakültesi, Çocuk Gelişimi Bölümü, hciftci@istinye.edu.tr
} 


\section{SUMMARY}

\section{Introduction}

Concept; it is the mental structure that represents organized knowledge such as object, event, action, quality and relationship. Grouping of objects, events, phenomena and thoughts according to their common characteristics constitutes the concept (Kaptan, 1998; Klausmeier, 1992). In pre-school period, children gain concepts of color, shape, space, measurement and mathematics through their experiences in daily life.

Mathematical concepts start to occur in early childhood and shaped by child's communication with the immediate surroundings (Lovell, 1971; Frakes and Kline, 2000; Geist, 2001). Every child in preschool starts earning concepts of mathematics by trying exploring and comparing in everyday life. This process occurs when children play and experience in daily activities. These discoveries may be different level for each child. Teachers should take into account these levels and differences in children's mathematical skills while prepare programs and plan activities to meet children's needs (Wortham, 2006; Uyanık and Kandır, 2010; Kandır and Orçan, 2010).

In the pre-school period, one of the methods used to give children mathematics skills is drama. Children actively participate in activities and learning by living and doing through drama. The use of drama as a method of learning in education contributes to the mental development of children in preschool period (Bayram vd., 1999; Eğitmen, 1999; Koç, 1999). Drama progressively improves problem-solving skills in children at the same time develops critical thinking skills (San, 1996; Şentürk, 1996; Üstündăg, 1996). From this way, in pre-school period, drama studies that will be prepared taking into consideration the developmental characteristics of children in terms of number concept mathematic skills such as addition, subtraction, rhythm counting, matching, finding the missing number symbol, will accelerate their mathematical concept development and contribute concept learning. In this research, it was aimed to determine the mathematical skills of 5-6 year old children to gain these skills with creative drama method.

\section{Method}

The working model is designed as a two-group and semi-experimental. The research was conducted on total of 60 children, 30 in the experimental group and 30 in the control group. 24 (40\%) of the children are girls, $36(60 \%)$ are males and $42(70 \%)$ are 5 years old and $18(6 \%)$ are 6 years old. "Personal Information Form" organized by the researcher was used as a data collection tool to collect demographic information. In order to determine the skills of children towards the concept of numbers, 'Number and Process Concept Tests for Children 5-6 years' developed by Arnas, Gül and Sığırtmaç (2003) were applied. 
When starting the analysis of the data, experimental and control groups were determined in terms of differed pre-test scores. We wanted to use the ANCOVA analysis to eliminate this disparity but could not because the assumptions were not met. In order to examine the effectiveness of the application, analyzes were examined in terms of gain scores. Differences in demographic variables were compared with pre-test scores as it was more important in terms of giving correct information compared to the situation before the application. The variables with normality distribution and have two independent categories; $t$ test was applied, besides Mann Whitney $U$ test was used for the variables with no normal distribution. Because the number of least one category observations low in variables with more than two categories, Kruskal Wallis H test was used.

\section{Results}

According to sex of children, total test scores do not show any significant difference among rhythmic counting, number recognition, individual matching, number position, number writing, summation, subtraction sub-dimensions and number concept $(p>0,05)$; but, the number symbol sorting subdimension is significantly different by sex $(p<0,05)$. It is seen that the average of female children for the number symbol sorting sub-dimension is higher than male children.

The total scores of rhythmic counting, number recognition, individual matching, number position, number symbol sorting, summation, sub-dimensions and number concept test do not show any significant difference according to children's ages ( $p>0,05)$; but, the number writing and subtraction subdimension is significantly different by age $(p<0,05)$. When the averages are examined, writing subdimension scores of six-year-old children higher than the five-year-old children's scores; on the contrary, for the subtraction subscale, the average scores of five-year-old children higher than the six-year-old children's average scores.

It is seen that the total scores of rhythmic counting, digit recognition, individual matching, number position, number symbol sorting, number writing, summation, subtraction sub-dimensions and number concept test did not significantly differ according to the age of children $(p>0,05)$. On the other hand, regardless of whether they continue to the school, the level of children's concept of numbers is similar. The gain points are different for the total score of the experiment and control group rhythmic counting, number recognition, individual matching, number position, number symbol sorting, number writing, summation, subtraction subdimensions and number concept test. When the averages are examined, it is shown that this difference is favoring the experiment group for all dimensions. In other words, the applied creative drama program has been influential in the development of children's number concept positively.

\section{Conclusion and Discussion}

The significance of the difference between the scores of the experimental and control groups was tested to assess the effectiveness of the drama program on the development of number concept in the 
experimental group. For all dimensions it was seen that the averages of the test group were clearly higher than the control group. In other words, the creative drama program applied to the experimental group of five to six years has been influential in the development of children's number concept. Bulut Pedük's study (2007), examining the effect of children mathematical ability by providing mathematics education based on multiple intelligence theory to the children aged six years, supports the results we obtained.

When it is examined, the mathematical skills of five-years age groups and similar studies regarding number concept acquisition; there were more significant differences between pre-test and post-test scores of experimental groups than control groups because of applied training programs and the results of the training experimental groups' children received. (Ürkün, 1992; Tarım-Gözübatık and DeretarlaGül, 2004; Young-Loveridge, 2004).

As a result of the research, it was determined that female children were more successful in numerical symbol sorting subscale than male children. In similar studies, the methods based on the supporting education model of the creative drama have been used in order to giving the number concept, as a result of these investigations it was observed that there was no difference according to sex in terms of mathematics scores (Ürkün, 1992; Güven, 1997; Karataş, 1996; Güven;2000). However, when the literature is examined, it is seen that the differences between the sexes increase with the increase of the age (Benhow, 1988; Benhow and Stanley, 1980; Benhow and Stanley, 1983).

As a result of the examination regarding ages; children aged six years are more successful in the ability of write numbers, while children aged five years are more successful in the ability to substraction. Güven (1997) examined the effect of Early Mathematical Ability Test-2's validity, reliability, normative study and mathematical ability of sociocultural factors in his research. As a result of the research, it was determined that the mathematical ability average scores of children in the age range of 3-5 are lower than the average of the children in the age range of $6-8$ years. 


\section{GİRIŞ}

Doğumdan itibaren başlayarak yaşam boyu devam eden eğitim, çocukluk dönemi açısından oldukça önemlidir. Günümüzde bu farkındalık ile okul öncesi eğitim, bilimsel düşünce ile temellendirilerek geliştirilmeye ve yaygınlaştırılmaya çalışılmaktadır.

Kişiliğin temellerinin atıldı̆̆ı; sosyal, bilişsel ve psikomotor gelişimin azami ölçüde desteklenmesi gereken okul öncesinde eğitim, rastlantılara yer verilmeksizin sürdürülmesi gereken en temel sistem olarak karşımıza çıkmaktadır. Bireyin yaşamını kolaylaştırması ve yeteneklerini geliştirmesinde önemli rol oynayan matematiksel kavramların, okul öncesi dönemde çocuklara kazandırılması, farklı alanlardaki bilgi ve becerilerinin gelişimine katkı sağlamaktadır (Yıldız, 1999; Arı,2003; Arı, 2007; Güven, 2000; Sezer, 2008).

Kavram; obje, olay, eylem, nitelik ve ilişki gibi organize edilmiş bilgiyi temsil eden zihinsel yapıdır. Obje, olay, olgu ve düşüncelerin sahip olduğu ortak özelliklere göre gruplandırılması kavramı oluşturmaktadır (Kaptan, 1998; Klausmeier, 1992).

Akyürek (2004) kavramı; "Bireyin yaşantıları sonucu obje ve olayların ortak özelliklerinden soyutlanarak elde edilen ve sembollerle ifade edilen düşünme ürünüdür” şeklinde tanımlamıştır. Kavram, farklı obje ve olguların değişkenlik gösteren ortak özelliklerini temsil ederek insan zihninde anlamlanan bilgi formudur. Nesneler, özellikleri doğrultusunda düşüncelerle benzerlik göstererek zihinde kavramsal bir grup oluşturmaktadır (Kurtuluş, 1999; Güven, 2000; Ülgen, 2004).

Çocuğun temel kavramları edindiği erken çocukluk dönemi, gelişimin en hızlı gerçekleştiği dönem olarak bilinmektedir. Okul öncesi dönemde, çocuklar günlük yaşantılarında edindikleri deneyimleri yoluyla renk, şekil, mekan, ölçme ve matematik kavramlarını kazanmaktadırlar (Yıld1z, 1999; Frakes and Kline, 2000; Jacobson, 2001).

Okul öncesi dönemde çocuğun öğrenme ortamlarının aktif öğrenme yöntemine uygun olması, deneyimleyerek yapmaya ve öğrenmede somuttan soyuta geçişi kolaylaştırırken, çocuğun ilerleyen yıllarda kazanacağı matematiksel becerilerin gelişimine ve kavram oluşumuna da katkı sağlamaktadır (Wortham, 1998; Güven, 2000; Young Loveridge, 2004). Erken çocukluk döneminde oluşmaya başlayan matematiksel kavramlar, çocuğun yakın çevresi ile olan iletişimi ile şekillenmektedir. Fiziksel sıralama ile başlayan matematiksel beceriler, zihinsel ve elle sıralandırma becerilerinin kazanımıyla devam etmektedir (Lovell, 1971; Frakes and Kline, 2000; Geist, 2001). 
Çocuklarda bilişsel gelişim yoluyla edinilen matematiksel beceriler, çocuğun kavram öğrenimi ile doğru orantılıdır (Küçükturan ve Eyidoğan, 2004; Ülgen, 2004; Şimşek, 2006). Bruner ve arkadaşları (1956), "Denence Sınama Kuramı" ile kavram öğrenimine bilişsel açıdan yaklaşmışlardır. Bu kurama göre öğrenme, bireyin kendi deneyimleriyle oluşturduğu yeni fikir ve kavramları kapsayan etkin bir süreçtir. Kazandığı bilgiyi deneyimleriyle işleyen birey, oluşturduğu kavramın doğruluğunu tecrübe etmek için bir strateji geliştirerek kavramı tanımlayan özelliklerin neler olduğuna dair tahminlerini sınamaktadır (Kandır, 2010; Kandır ve Orçan, 2010).

Okul öncesi dönemde matematiksel kavramları çocuklara somut deneyimlerle kazandırarak, oyunlarla deneyimledikleri sayısal kavram ve becerileri doğru örüntülemelerini sağlamak gelişim alanlarına sunduğu katkı açısından büyük önem taşımaktadır. Çocuklarda matematiksel kavramlar çevreyi keşfetme yoluyla ve tekrarlayan deneyimler sonucu öğrenilmektedir. Bu öğrenme süreci çocuğun objeleri sıralamada, doğru rakam kullanmasıyla devam etmektedir (Maxim, 1989; Dere, 2000). Okul öncesi eğitim programlarının birçok alanında kullanılan matematiksel kavramlar, çocukların günlük yaşantılarının içinde yer almaktadır (Akman vd., 2000; Dere, 2000). Bu dönemde çocukta kazandırılması hedeflenen kavramların, gelişim düzeylerine uygun olarak, öğrenme ortamlarında oyun ile birleştirilerek verilmesi, öğrenmeyi eğlenceli hale getirerek kolaylaştırmaktadır (Metin, 1992).

Çocuğun matematiksel kavram kazanımı sayıları anlamlandırma ile başlarken ilerleyen dönemlerde somut nesnelerle sayıların birleştirilmesini hedefleyerek devam etmektedir. Çocuğa sembolleri kullanmayı öğreten bu somutlama ile çocuk matematiği öğrenmeye hazır hale gelmektedir (Zhou ve Wang, 2004). Okul öncesi dönemde matematiksel kavramlar; fendoğa çalışmaları, dramatik çalışmalar, müzik etkinlikleri, masa başı çalışmalar ve drama ile kazandırılmaktadır. Türkçe dil etkinlikleri, okuma yazmaya hazırlık ve oyun etkinlikleri ile birlikte verilmektedir. Sınıflarda oluşturulan matematik becerilerine yönelik hazırlanan ilgi merkezleri ile çocukların nesneler yardımıyla deneyimler kazanması amaçlanmaktadır. Okul öncesinde matematik öğrenimi ile çocuklar nesneleri sınıflandırarak daha etkili düşünmeyi sağlamakta ve deneyimlenmiş bilgilerle yeni yaşantılarına anlam kazandırmaktadır. Mantıklı düşünme ve muhakeme yapmada önemli bir araç olan matematik öğrenimi, çocuklara öğrenilmiş bilgilerini organize edebilmeleri için etkili bir sistem oluşturmaktadır.

Okul öncesi dönem çocuklarında matematiksel gelişimin ilk ve en önemli basamağı; sayılar ve sayıların anlamını geliştirmektir. Sayı kavramı geliştirildiğinde eşleştirme, sıralama ve sınıflandırma gibi kavramların kazanımı kolaylaşmaktadır (Güven, 2000; Kandır ve Orçan, 
2010). Okul öncesinde çocukların sayı kavramını anlamlandırmaları somut nesnelerin kullanımıyla sağlanmaktadır. Çocuğun çevreden edindiği deneyimler, sayı kavramını anlama, sıralama, gruplama gibi becerilerin kazanılmasına yardımcı olmaktadır (Kritou, Eteokleous ve Gregoriu, 2005).

Okul öncesi dönemde sayı kavramını geliştirmeye yönelik yapılan benzer araştırmalar incelendiğinde; matematiksel kavramların dünyadaki nesneleri tanımlayarak, çocukların edindikleri sayı kavramı becerileri ile birlikte; önemli bilişsel işlevlerin gerçekleştirilmesine olanak sağladıkları görülmektedir (Benhow ve Stanley, 1980; Benhow, 1988; Ürkün, 1992; Karataş, 1996; Güven, 2000; Sezen, 2008; Sucuoğlu vd., 2008).

Okul öncesi dönemde, çocuklara matematik becerilerini kazandırmada kullanılan yöntemlerden birisi dramadır. Drama yoluyla çocuklar yaparak yaşayarak öğrenirken etkinliklere aktif olarak katılmakta ve oynayarak öğrenme firsatı bulmaktadırlar. Dramanın eğitimde öğrenme yöntemi olarak kullanılması, okul öncesi dönemde çocukların zihinsel gelişimlerine katkı sağlamaktadır (Bayram vd., 1999; Eğitmen, 1999; Koç, 1999). Drama çocuklarda problem çözme becerilerinin gelişimini aşamalar halinde sağlarken aynı zamanda eleştirel düşünme becerilerini de geliştirmektedir. (San, 1996; Şentürk, 1996; Üstündağ, 1996).

Eğitimde yer alan bazı derslerin amaçlarına etkili ulaşmada yaratıcı drama, etkin kullanılabilecek yöntemsel bir işlev görevindedir. Yaratıcı dramanın sahip olduğu teknikler bir yöntem ya da araç olma durumunda da eğitime hizmet etmektedir. Yaratıcı drama teknikleri yöntemi işlevsel hale getirmekte, fiile büründürmektedir. Bu özellikleri ile drama eğitim ve öğretimde aktif olarak kullanılmaktadır (Adıgüzel, 2012; Sağlam, 2004; Genç, 2005).

Buradan yola çıkılarak, okul öncesi dönemde matematik becerilerinden; toplama, çıkarma, ritmik sayma, eşleştirme, eksik sayı sembolünü bulma gibi sayı kavram becerilerini kazandırmada, çocukların gelişimsel özellikleri dikkate alarak hazırlanacak olan drama çalışmaları, onların matematiksel kavram gelişimlerine katkı sağlayarak kavram öğrenimini hızlandıracaktır. Bu araştırmada da 5-6 yaş çocukların matematiksel becerileri belirlenerek yaratıcı drama yöntemi ile bu becerilerin kazandırılması amaçlanmıştır.

Ayrıca 5-6 yaş çocuklarının matematiksel becerilerini etkileyen faktörleri incelemek bu çalışmanın diğer bir amacıdır. Bu amaçlar doğrultusunda aşağıdaki sorulara yanıt aranmıştır?

- Yaratıcı drama uygulaması öncesinde kontrol ve deney gruplarında 5-6 yaş çocukların matematiksel becerileri anlamlı farklılık göstermekte midir? 
- Yaratıcı drama uygulaması sonrasında kontrol ve deney gruplarında 5-6 yaş çocukların matematiksel becerileri erişi puanları anlamlı farklılık göstermekte midir?

- 5-6 yaş çocukların matematiksel becerileri cinsiyetleri, yaşları ve okula devam sürelerine göre anlamlı farkl1lık göstermekte midir?

\section{YÖNTEM}

\section{Araştırmanın Modeli}

Çalışmanın modeli iki gruplu yarı deneysel model olarak tasarlanmıştır. Okullarda yapılan eğitim araştırmalarıyla ilgili çalışmalarda, hazır bulunan sınıfların direk çalışmaya alınması nedeniyle, araştırma gurupları tam olarak tarafsız eşitlenerek uygulamaya dahil edilmediği için bu tarz araştırmalarda yöntem olarak yarı deneysel model kullanılması daha uygundur (Baştürk, 2101). Yarı deneme modellerinden eşitlenmemiş kontrol gruplu modelde gruplar rastgele ve benzer özellikler taşımalarına dikkat edilerek oluşturulmaktadır (Karasar, 2014).

\section{Çalışma Grubu}

Araştırma Ankara ilinde tesadüfi yöntemle belirlenen iki okul öncesi özel eğitim kurumunda eğitim gören beş ve altı yaş çocuklarla çalışılarak hazırlanmıştır. Okul öncesi eğitim kurumundaki toplam 120 çocuğun aileleri ile veli görüşmeleri yapılarak çalışmanın içeriği ve kapsamı hakkında bilgi verilmiştir. Çalışmaya katılmayı kabul eden ailelere "Kişisel Bilgi Formu”, çocuklara ise '5-6 Yaş Çocuklar İçin Sayı ve İşlem Kavramları Testi' uygulanmıştır. Uygulanan ön test sonucunda yaş grubuna göre ortalamanın altında puan alan çocuklar seçilerek, tesadüfi yöntemle her bir okul öncesi eğitim kurumundan on beş deney, on beş kontrol olmak üzere otuz kişilik deney ve kontrol grubu oluşturulmuştur. İki okul öncesi eğitim kurumundan otuz deney, otuz kontrol grubunu tamamlayan altmış çocukla çalışılmıştır. Uzman görüşleri alınarak sayı ve işlem kavramlarının gelişimine yönelik hazırlanmış olan drama planları, iki okul öncesi eğitim kurumunda bulunan 15'er kişilik iki deney grubuna da altı hafta süreyle, haftada iki gün iki saat olarak uygulanmıştır. Uygulama sonrasında deney ve kontrol gruplarına son testler uygulanmıştır.

30'u deney grubunda ve 30'u kontrol grubunda olmak üzere toplam 60 çocuk üzerinden yürütülen çalışmada çocukların 24'ü (\%40’1) kız, 36'sı (\%60'1) erkek ve 42'si (\%70'i) beş yaşında, 18'i (\%30’u) altı yaşındadır.

Çalışma grubunda yer alan çocuklar, anneleri ve babalarına ait demografik bilgiler Tablo 1'de sunulmuştur. 
Tablo 1. Demografik Bilgilere İlişkin Frekans Dă̆ıllımı

\begin{tabular}{|c|c|c|c|c|c|c|c|}
\hline & & $\mathrm{N}$ & $\%$ & & & $\mathrm{n}$ & $\%$ \\
\hline \multirow{3}{*}{ Cinsiyet } & $\mathrm{K}_{1 \mathrm{Z}}$ & 42 & 70,0 & \multirow{6}{*}{$\begin{array}{l}\text { Baba } \\
\text { Eğitim }\end{array}$} & Okuryazar & 1 & 1,7 \\
\hline & Erkek & 18 & 30,0 & & Lise ve dengi & 11 & 18,3 \\
\hline & Toplam & 60 & 100,0 & & Meslek yüksekokulu & 1 & 1,7 \\
\hline \multirow{3}{*}{$\begin{array}{l}\text { Çocuğun } \\
\text { Yaşı }\end{array}$} & 5 yaş & 24 & 40,0 & & Üniversite & 42 & 70,0 \\
\hline & 6 yaş & 36 & 60,0 & & Yüksek lisans/doktora & 5 & 8,3 \\
\hline & Toplam & 60 & 100,0 & & Toplam & 60 & 100,0 \\
\hline \multirow{7}{*}{$\begin{array}{l}\text { Kaç yaşından } \\
\text { beri okul } \\
\text { öncesi } \\
\text { kurumuna } \\
\text { devam } \\
\text { ediyor? }\end{array}$} & 1 yaş & 7 & 11,7 & \multirow{8}{*}{$\begin{array}{l}\text { Anne } \\
\text { Meslek }\end{array}$} & Memur & 28 & 46,6 \\
\hline & 2 yaş & 10 & 16,7 & & İşçi & 4 & 6,7 \\
\hline & 3 yaş & 15 & 25,0 & & Sağlık personeli & 6 & 10,0 \\
\hline & 4 yaş & 6 & 10,0 & & Hakim/Savc1 & 1 & 1,7 \\
\hline & 5 yaş & 17 & 28,3 & & Mühendis/mimar & 3 & 5,0 \\
\hline & 6 yaş & 5 & 8,3 & & Serbest meslek & 1 & 1,7 \\
\hline & Toplam & 60 & 100,0 & & Ev hanımı & 17 & 28,3 \\
\hline \multirow{3}{*}{ Anne Yaş } & 35 yaş ve altı & 39 & 65,0 & & Toplam & 60 & 100,0 \\
\hline & 36 yaş ve üstü & 21 & 35,0 & \multirow{7}{*}{$\begin{array}{l}\text { - Baba } \\
\text { - Meslek }\end{array}$} & Memur & 20 & 33,3 \\
\hline & Toplam & 60 & 100,0 & & İşçi & 11 & 18,3 \\
\hline \multirow{3}{*}{ Baba Yaşı } & 35 yaş ve altı & 26 & 43,3 & & Sağlık personeli & 2 & 3,3 \\
\hline & 36 yaş ve üstü & 34 & 56,7 & & Hakim/Savc1 & 1 & 1,7 \\
\hline & Toplam & 60 & 100,0 & & Mühendis/mimar & 12 & 20,0 \\
\hline \multirow{6}{*}{ Anne Eğitim } & İlkokul & 1 & 1,7 & & Serbest meslek & 14 & 23,4 \\
\hline & Lise ve dengi & 13 & 21,6 & & Toplam & 60 & 100,0 \\
\hline & Meslek yüksekokulu & 1 & 1,7 & \multirow{3}{*}{$\begin{array}{l}\text { Aylık } \\
\text { - Gelir }\end{array}$} & $2001-4000 \mathrm{TL}$ & 17 & 28,3 \\
\hline & Üniversite & 42 & 70,0 & & 4001 TL ve üstü & 43 & 71,7 \\
\hline & Yüksek lisans/doktora & 3 & 5,0 & & Toplam & 60 & 100,0 \\
\hline & Toplam & 60 & 100,0 & & & & \\
\hline
\end{tabular}

Tablo 1'e göre araştırmaya katılan çocukların cinsiyete göre dağılımları incelendiğinde deney grubundaki çocukların \%43,3'ünün kı, \%56,7'sinin erkek çocuk olduğu; kontrol grubunda ise \%36,7'sinin kız, \%63,3'ünün erkek çocuk olduğu görülmektedir. Çocukların yaşlarına göre dağılımları incelendiğinde deney grubundaki çocukların \%66,7'sinin kı, \%33,3'ünün erkek çocuk olduğu; kontrol grubunda ise \%73,3'ünün k1z, \%26,7'siin erkek çocuk olduğu tespit edilmiştir. Çocukların \%11,7'sinin 1 yaşından itibaren, \%16,7'sinin 2 yaşından itibaren, \%25'inin 3 yaşından itibaren, \%10'unun 4 yaşından itibaren, $\% 28,3$ 'ünün 5 yaşından itibaren ve \%8,3'ünün 6 yaşından itibaren okul öncesi eğitim kurumlarına devam etmektedir. Çocukların annelerinin yaşlarına göre dağılımlarına bakıldığında deney grubu için annelerin yarısından çoğunun $(\% 66,7) 35$ yaş ve altında olduğu, \%33,3'ünün ise 36 yaş ve üzerinde olduğu tespit edilmiştir. Kontrol grubu için de benzer şekilde annelerin yarısından çoğunun $(\% 63,3) 35$ yaş ve altında olduğu, \%36,7’sinin ise 36 yaş ve üzerinde olduğu görülmektedir. 


\section{Veri Toplama Araçları}

Veri toplama aracı olarak demografik bilgileri toplamak amacıyla araştırmacı tarafindan düzenlenen "Kişisel Bilgi Formu" kullanılmıştır. Çocukların sayı kavramına yönelik becerilerini tespit etmek amacıyla ise Arnas, Gül ve Sığırtmaç (2003) tarafından geliştirilen '56 Yaş Çocuklar İçin Sayı ve İşlem Kavramları Testi' uygulanmıştır. Testin uygulama izni araştırmacılardan alınmıtır.

\section{Kişisel Bilgi Formu}

Araştırmacı tarafindan düzenlenen demografik bilgileri toplamak amacıyla hazırlanan kişisel bilgi formunda, araştırmaya dahil edilen çocukların cinsiyeti, yaşı, okul öncesi kurumuna devam etme yaşı, anne ve babasının yaşı, eğitim düzeyi, mesleği ve ailenin aylık gelirine ilişkin sorular yer almaktadır. Çalışma öncesinde velilerle toplantı düzenlenerek, araştırmacı tarafından hazırlanan çocuklar ve aileleriyle ilgili soruları içeren on soruluk kişisel bilgi formunun doldurulması istenmiştir. Veli onayı alınmayan çocuklar çalışmaya dahil edilmemiştir.

\section{5-6 Yaş Çocuklar İçin Sayı ve İşlem Kavramları Testi}

Çocukların sayı kavramına ilişkin becerilerinin tespit edilmesi amacıyla Arnas, Gül ve Sığırtmaç (2003) tarafından geliştirilen 5-6 Yaş Çocuklar İçin Sayı ve İşlem Kavramları Testi çocukların, ritmik sayma (ileri doğru, geriye doğru ritmik sayma, ritmik sayarken atlanılan rakamı bulma), rakam tanıma (söylenen rakamı gösterme, gösterilen rakamı söyleme, rakam kartlarını eşleştirme), birebir eşleştirme (üç grup nesneden ve üç resim kartından eşit olanları eşleştirme, resim kartındaki nesne sayısı ile sayı sembolünü eşleştirme), sayı korunumu (nesneleri sayarak kaç tane olduğunu söyleme ve sayı sembolünü gösterme, verilen rakamın ifade ettiği kadar nesneyi gösterme, üç grup nesneyi sayarak “?” olan yere gelmesi gereken nesne sayısına ait rakam kartını bulma), sayı sembolü sıralama (sayı sembollerini sıraya dizme, söylenen sıradaki nesneyi gösterme, gösterilen sıradaki nesnenin kaçıncı sırada olduğunu söyleme), rakam yazma (gösterilen rakamı yazma, söylenen rakamı yazma), toplama (söylenen toplama işlemini yapma, somut nesnelerle toplama, gösterilen toplama işleminin sonucunu söyleme), çıkartma (söylenen çıkartma işlemini yapma, somut nesnelerle çıkartma, gösterilen çıkartma işleminin sonucunu söyleme) matematik becerilerine yönelik soruları içermektedir. Çocukların testten aldıkları başarı puanları testin değerlendirme çizelgesine göre belirlenmiştir. Arnas, Gül ve Sığırtmaç (2003), tarafından 865 çocuk ile geçerlilik ve güvenirlik çalışması yapılan bu test; sayma, rakam yazma, rakam tanıma, eşleştirme, korunum, sıra sayıları ve 
toplama-çıkarma işlemleri gibi çocukların sayı ve işlem yeteneklerini farklı açılardan ölçen 89 sorudan oluşmaktadır. Testin güvenirliğini belirlemek amacıyla iç tutarlılık katsayısı hesaplanmış ve KR-20 değeri tüm test için .98, test tekrar test için hesaplanan Pearson Momentler Çarpımı Korelasyon Katsayısı $r=.95$ olarak bulunmuştur. 6 yaş grubu için iç tutarlılık katsayısı .97 olarak bulunmuştur.

\section{Verilerin Toplanması ve Uygulama Süreci}

Tesadüfi yöntemle Ankara ilinde belirlenen iki adet özel okul öncesi eğitim kurumunda eğitim gören 5- 6 yaş aralığında toplam 120 çocuğun aileleri ile veli görüşmeleri yapılmış, çalışmanın içeriği ve kapsamı hakkında etik ilkeler doğrultusunda bilgi verilmiştir. Çalışmaya katılmayı kabul eden ailelere "Kişisel Bilgi Formu”, çocuklara ise Arnas, Gül ve Sığırtmaç (2003) tarafından geliştirilen '5-6 Yaş Çocuklar İçin Sayı ve İşlem Kavramları Testi’ uygulanmıştır. Araştırmada deney ve kontrol grupları için sayı ve işlem kavramıyla ilgili eğitim programı araştırmacı tarafından hazırlanmıştır. Hazırlanan eğitim programlarının pilot uygulaması yapılmış, uzman görüşleri alınmış ve eksiklikler giderilerek yeniden düzenlenmiştir. Testlerin uygulaması veli onay formları ve çalışmanın yapıldığı okul müdürü bilgilendirmesinden sonra başlatılmıştır. Testler okulların rehber öğretmen sınıflarında, çocuk ile birebir olarak uygulanmıştır. Ön test sonucunda alınan toplam puanlar toplam sayıya bölündügünde ortalama olarak alınması gereken puan belirlenmiştir. Yaş grubuna göre genel ortalamanın altında puan alan çocuklar, tesadüfi yöntemle, her bir okul öncesi eğitim kurumunda, on beşer kişilik deney ve kontrol grubu olmak üzere iki gruba ayrılmıştır. Yani çalışmaya katılan beş ve altı yaş çocukların 30’u deney, 30’u kontrol grubunu oluşturmuştur. İki okul öncesi eğitim kurumunda otuz deney, otuz kontrol grubu olmak üzere altmış çocukla çalışılmıştır. Matematiksel becerileri içeren 12 haftalık drama planları hazırlanarak drama planlarının uzman görüşü alındıktan sonra her iki okul öncesi eğitim grubundaki deney gruplarına altı hafta süreyle, haftada iki gün iki saat olarak uygulanmıştır. Hazırlanan planlar, okul öncesi dönemde matematik becerilerinden; toplama, çıkarma, ritmik sayma, eşleştirme, eksik sayı sembolünü bulma gibi sayı kavram becerilerini kazandırmada, çocukların gelişimsel özellikleri dikkate alarak hazırlanmıştır. Planlar 1sınma, canlandırma ve değerlendirme bölümlerinden oluşmaktadır.

Çalışmada öncelikli olarak iki grup seçilmiş, biri deney ve biri kontrol grubu olarak atanmıştır. Ön uygulama yapılarak araştırmaya katılan çocukların yapılan işlemden önce incelenen özelliğe sahip oluş düzeyleri incelenmiştir. Ön test uygulamasından sonra deney grubuna araştırmacı tarafindan hazırlanan yaratıcı drama programı uygulanmış, kontrol grubuna ise 
herhangi bir uygulama yapılmamıştır. Son olarak hem deney grubuna hem de kontrol grubuna son test uygulanarak verilerin analizi yapılmıştır.

Tablo 2. İki Gruplu Yarl Deneysel Model

\begin{tabular}{cccc}
\hline Grup & Ön Test & İşlem & Son Test \\
\hline Deney & $\ddot{O}_{1}$ & $\mathrm{X}$ & $S_{1}$ \\
\hline Kontrol & $\ddot{O}_{2}$ & & $S_{2}$ \\
\hline
\end{tabular}

\section{Verilerin Analizi}

Araştırmada ele alınan değişkenler için analiz türü belirlenmeden önce değişkenlerin normal dağılım gösterip göstermediği incelenmiştir. Normal dağılım varsayımı incelenirken basıklık, çarpıklık değerleri ve normallik testleri (kolmogorov-smirnove ile shapiro-wilk) sonuçları birlikte incelenerek karar verilmiştir. Deney ve kontrol grubu ön test puanları açısından farklılık gösterdiği için öncelikle kovaryans analizi (ANCOVA) ile bu farklılığın etkisinin kaldırılması planlanarak analizin varsayımları incelenmiş ancak sağlanmadığı görülmüştür. Bu nedenle yapılan uygulamanın etkililiğini incelemek için analizler erişi puanları açısından incelenmiştir. Demografik değişkenler açısından farklılık incelenirken ise çocukların uygulama yapılmadan önceki duruma göre karşılaştırılması doğru bilgi vermesi açısından daha önemli görüldüğü için ön test puanları üzerinden karşılaştırma yapılmıştır. Normallik dağılımı gösteren ve iki bağımsız kategoriye sahip olan değişkenler için ilişkisiz örneklemler t test; normal dağılıma sahip olmayan değişkenler için ise Mann Whitney U testi uygulanmıştır. İkiden fazla kategoriye sahip değişkenler için en az bir kategorideki gözlem sayısı düşük olduğundan Kruskal Wallis H testi kullanılmıştır.

\section{BULGULAR}

56 yaş çocuklarına 'Ritmik Sayma, Rakam Tanıma, Birebir Eşleştirme, Sayı Konumu, Sayı Sembolünü Sıralama, Rakam Yazma, Toplama, Çıkartma' matematik becerilerini kazandırmada drama çalışmalarının etkisini incelemek amacıyla yapılan çalışmanın bulguları aşağıda sunulmuştur.

Çocuklarının cinsiyetine göre sayı kavramı düzeylerinin farklılaşıp farklılaşmadığına incelemek için ilişkisiz örneklemler t-testi kullanılmış ve sonuçlar Tablo 3 'te sunulmuştur. 
Tablo 3. Çocukların Cinsiyetine Göre Sayı Kavramı Düzeylerine İlişkin Ön Test Puanlarının Farklılaşmasına Ait İlişkisiz Örneklemler T-Testi Sonuçları

\begin{tabular}{|c|c|c|c|c|c|c|c|}
\hline & & $\mathrm{n}$ & $\bar{X}$ & ss & $\mathrm{sd}$ & $\mathrm{t}$ & $\mathrm{p}$ \\
\hline \multirow{2}{*}{ Ritmik Sayma } & $\mathrm{K}_{1 \mathrm{Z}}$ & 24 & 2,25 & 1,39 & \multirow{2}{*}{58} & \multirow{2}{*}{1,318} & \multirow{2}{*}{0,193} \\
\hline & Erkek & 36 & 2,83 & 1,84 & & & \\
\hline \multirow{2}{*}{ Rakam Tanıma } & $\mathrm{K}_{1 \mathrm{z}}$ & 24 & 10,25 & 3,84 & \multirow{2}{*}{58} & \multirow{2}{*}{0,884} & \multirow{2}{*}{0,380} \\
\hline & Erkek & 36 & 11,11 & 3,60 & & & \\
\hline \multirow{2}{*}{ Birebir Eşleştirme } & $\mathrm{K}_{1 \mathrm{Z}}$ & 24 & 3,08 & 1,67 & \multirow{2}{*}{58} & \multirow{2}{*}{1,748} & \multirow{2}{*}{0,086} \\
\hline & Erkek & 36 & 2,33 & 1,60 & & & \\
\hline \multirow{2}{*}{ Sayı Konumu } & $\mathrm{K}_{1 \mathrm{Z}}$ & 24 & 7,29 & 3,72 & \multirow{2}{*}{58} & \multirow{2}{*}{1,949} & \multirow{2}{*}{0,056} \\
\hline & Erkek & 36 & 5,58 & 3,04 & & & \\
\hline \multirow{2}{*}{ Sayı Sembolünü Sıralama } & Kiz & 24 & 3,50 & 1,56 & \multirow{2}{*}{58} & \multirow{2}{*}{2,167} & \multirow{2}{*}{$0,034^{*}$} \\
\hline & Erkek & 36 & 2,61 & 1,55 & & & \\
\hline \multirow{2}{*}{ Rakam Yazma } & $\mathrm{K}_{1 \mathrm{z}}$ & 24 & 5,88 & 3,05 & \multirow{2}{*}{58} & \multirow{2}{*}{0,845} & \multirow{2}{*}{0,402} \\
\hline & Erkek & 36 & 5,25 & 2,63 & & & \\
\hline \multirow{2}{*}{ Toplama } & $\mathrm{K}_{1 \mathrm{z}}$ & 24 & 7,04 & 3,53 & \multirow{2}{*}{58} & \multirow{2}{*}{0,250} & \multirow{2}{*}{0,803} \\
\hline & Erkek & 36 & 6,81 & 3,61 & & & \\
\hline \multirow{2}{*}{ Çıkartma } & Kiz & 24 & 7,29 & 4,15 & \multirow{2}{*}{58} & \multirow{2}{*}{0,352} & \multirow{2}{*}{0,726} \\
\hline & Erkek & 36 & 7,67 & 3,97 & & & \\
\hline \multirow{2}{*}{ Sayı Kavramı Testi Toplam Puan } & $\mathrm{K} 1 \mathrm{Z}$ & 24 & 46,58 & 13,22 & \multirow{2}{*}{58} & \multirow{2}{*}{0,718} & 0475 \\
\hline & Erkek & 36 & 44,19 & 12,20 & & & $0,4 / 3$ \\
\hline$* \mathrm{p}<0,05$ & & & & & & & \\
\hline
\end{tabular}

Tablo 3'e göre çocukların cinsiyetine göre ritmik sayma, rakam tanıma, birebir eşleştirme, sayı konumu, rakam yazma, toplama, çıkartma alt boyutları ve sayı kavramı testi toplam puanları anlamlı farklılık göstermez iken ( $p>0,05)$; sayı sembolünü sıralama alt boyutu cinsiyete göre anlamlı farklılık göstermektedir $(p<0,05)$. Sayı sembolünü sıralama alt boyutu için kız çocukların ortalamalarının erkek çocuklardan daha yüksek olduğu görülmektedir. Diğer bir deyişle sayı kavramının sayı sembolü sıralama alt boyutunda kız çocuklarından elde edilen veriler, erkek çocuklara göre daha anlamlıdır.

Çocuklarının yaşına göre sayı kavramı düzeylerinin farklılaşıp farklılaşmadığına incelemek için Mann Whitney U testi kullanılmıştır ve sonuçlar Tablo 4'te sunulmuştur. 
Tablo 4. Çocukların Yaşlarına Göre Sayı Kavramı Düzeylerine İlişkin Ön Test Puanlarına Ait Mann Whitney U Testi Sonuçları

\begin{tabular}{|c|c|c|c|c|c|c|}
\hline & & $\mathrm{n}$ & $\begin{array}{c}\text { Sira } \\
\text { Ortalamas1 }\end{array}$ & $\begin{array}{c}\text { Sira } \\
\text { Toplamı } \\
\end{array}$ & $\mathrm{Z}$ & $\mathrm{p}$ \\
\hline \multirow{2}{*}{ Ritmik Sayma } & 5 yaş & 42 & 32,07 & 1347,00 & \multirow{2}{*}{1,092} & \multirow{2}{*}{0,275} \\
\hline & 6 yaş & 18 & 26,83 & 483,00 & & \\
\hline \multirow{2}{*}{ Rakam Tanıma } & 5 yaş & 42 & 28,35 & 1190,50 & \multirow{2}{*}{1,495} & \multirow{2}{*}{0,135} \\
\hline & 6 yaş & 18 & 35,53 & 639,50 & & \\
\hline \multirow{2}{*}{ Birebir Eşleştirme } & 5 yaş & 42 & 31,93 & 1341,00 & \multirow{2}{*}{0,989} & \multirow{2}{*}{0,323} \\
\hline & 6 yaş & 18 & 27,17 & 489,00 & & \\
\hline \multirow{2}{*}{ Sayı Konumu } & 5 yaş & 42 & 29,13 & 1223,50 & \multirow{2}{*}{0,932} & \multirow{2}{*}{0,351} \\
\hline & 6 yaş & 18 & 33,69 & 606,50 & & \\
\hline \multirow{2}{*}{ Sayı Sembolünü Sıralama } & 5 yaş & 42 & 30,56 & 1283,50 & \multirow{2}{*}{0,041} & \multirow{2}{*}{0,967} \\
\hline & 6 yaş & 18 & 30,36 & 546,50 & & \\
\hline \multirow{2}{*}{ Rakam Yazma } & 5 yaş & 42 & 27,25 & 1144,50 & \multirow{2}{*}{2,218} & \multirow{2}{*}{$0,027 *$} \\
\hline & 6 yaş & 18 & 38,08 & 685,50 & & \\
\hline \multirow{2}{*}{ Toplama } & 5 yaş & 42 & 29,38 & 1234,00 & \multirow{2}{*}{0,761} & \multirow{2}{*}{0,447} \\
\hline & 6 yaş & 18 & 33,11 & 596,00 & & \\
\hline \multirow{2}{*}{ Çıkartma } & 5 yaş & 42 & 33,51 & 1407,50 & \multirow{2}{*}{2,050} & \multirow{2}{*}{$0,040 *$} \\
\hline & 6 yaş & 18 & 23,47 & 422,50 & & \\
\hline \multirow{2}{*}{$\begin{array}{c}\text { Sayı Kavramı Testi Toplam } \\
\text { Puan }\end{array}$} & 5 yaş & 42 & 29,36 & 1233,00 & \multirow{2}{*}{0,775} & \multirow{2}{*}{0,438} \\
\hline & 6 yaş & 18 & 33,17 & 597,00 & & \\
\hline$* \mathrm{p}<0,05$ & & & & & & \\
\hline
\end{tabular}

Tablo 4'e göre çocukların yaşlarına göre ritmik sayma, rakam tanıma, birebir eşleştirme, sayı konumu, sayı sembolünü sıralama, toplama, alt boyutları ve sayı kavramı testi toplam puanları anlamlı farklılık göstermez iken ( $p>0,05)$; rakam yazma ve çıartma alt boyutu yaşa göre anlamlı farklılık göstermektedir $(\mathrm{p}<0,05)$. Sira ortalamaları incelendiğinde rakam yazma alt boyutu için altı yaşındaki çocukların ortalamalarının beş yaş çocuklarına göre; çıkarma alt boyutu için beş yaşındaki çocukların ortalamaları altı yaş çocuklarına göre daha yüksektir. $\mathrm{Bu}$ durumun altı yaş çocuklarının okul öncesi deneyimlerinin, beş yaş çocuklarına göre daha fazla olmasından kaynaklandığı düşünülmektedir.

Çocuklarının okula devam sürelerine göre sayı kavramı düzeylerinin farklılaşıp farklılaşmadığını incelemek amacıyla Kruskal Wallis H testi kullanılmıştır. Sonuçlar Tablo 5'te sunulmuştur. 
Tablo 5. Çocukların Okula Devam Sürelerine Göre Sayı Kavramı Düzeylerine İlişkin Erişi Puanlarına Ait Kruskal Wallis H Testi Sonuçları

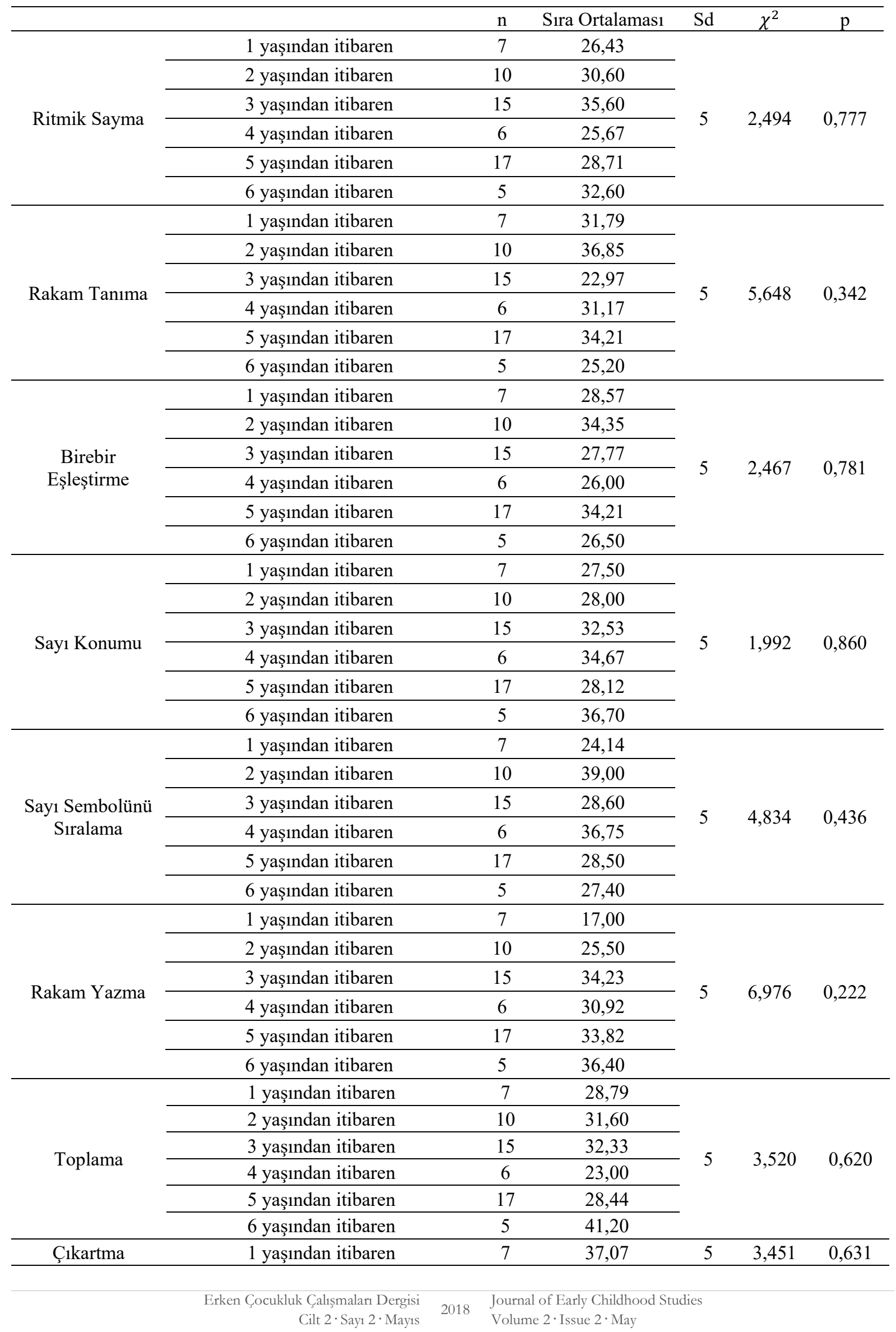




\begin{tabular}{|c|c|c|c|c|c|c|}
\hline & 2 yaşından itibaren & 10 & 35,85 & & & \\
\hline & 3 yaşından itibaren & 15 & 26,93 & & & \\
\hline & 4 yaşından itibaren & 6 & 25,83 & & & \\
\hline & 5 yaşından itibaren & 17 & 30,94 & & & \\
\hline & 6 yaşından itibaren & 5 & 25,40 & & & \\
\hline \multirow{6}{*}{$\begin{array}{c}\text { Sayı Kavramı } \\
\text { Testi Toplam } \\
\text { Puan }\end{array}$} & 1 yaşından itibaren & 7 & 23,36 & \multirow{6}{*}{5} & \multirow{6}{*}{2,029} & \multirow{6}{*}{0,845} \\
\hline & 2 yaşından itibaren & 10 & 32,50 & & & \\
\hline & 3 yaşından itibaren & 15 & 31,93 & & & \\
\hline & 4 yaşından itibaren & 6 & 25,92 & & & \\
\hline & 5 yaşından itibaren & 17 & 31,88 & & & \\
\hline & 6 yaşından itibaren & 5 & 33,00 & & & \\
\hline
\end{tabular}

Tablo 5 incelendiğinde çocukların okula kaç yaşından itibaren devam ettiklerine göre ritmik sayma, rakam tanıma, birebir eşleştirme, sayı konumu, sayı sembolünü sıralama, rakam yazma, toplama, çıkartma alt boyutları ve sayı kavramı testi toplam puanlarının anlamlı olarak farklılaşmadığı görülmektedir ( $p>0,05)$. Diğer bir okula devam durumuna bakılmaksızın çocukların sayı kavramı düzeyleri benzerdir.

Deney ve kontrol grubundaki çocukların sayı kavramı düzeylerinin uygulama öncesinde farklılaşıp farklılaşmadığını belirleyebilmek için ön test puanlarının farklılık gösterip göstermediği ilişkisiz örneklemler t-testi ile incelenmiş ve sonuçlar Tablo 6'da sunulmuştur.

Tablo 6. Deney ve Kontrol Gruplarının Sayı Kavramı Düzeylerine İlişkin Ön Test Puanlarının Farklılaşmasına Ait İlişkisiz Örneklemler T-Testi Sonuçları

\begin{tabular}{|c|c|c|c|c|c|c|c|}
\hline & & $\mathrm{n}$ & $\bar{X}$ & ss & $\mathrm{sd}$ & $\mathrm{t}$ & $\mathrm{p}$ \\
\hline \multirow{2}{*}{ Ritmik Sayma } & Deney & 30 & 2,17 & 1,32 & \multirow{2}{*}{58} & \multirow{2}{*}{2,039} & \multirow{2}{*}{$0,046^{*}$} \\
\hline & Kontrol & 30 & 3,03 & 1,92 & & & \\
\hline \multirow{2}{*}{ Rakam Tanıma } & Deney & 30 & 9,17 & 4,00 & \multirow{2}{*}{48,945} & \multirow{2}{*}{3,705} & \multirow{2}{*}{$0,001 *$} \\
\hline & Kontrol & 30 & 12,37 & 2,53 & & & \\
\hline \multirow{2}{*}{ Birebir Eşleştirme } & Deney & 30 & 2,17 & 1,70 & \multirow{2}{*}{58} & \multirow{2}{*}{2,256} & \multirow{2}{*}{$0,001 *$} \\
\hline & Kontrol & 30 & 3,10 & 1,49 & & & \\
\hline \multirow{2}{*}{ Sayı Konumu } & Deney & 30 & 5,30 & 3,78 & \multirow{2}{*}{52,609} & \multirow{2}{*}{2,276} & \multirow{2}{*}{$0,027^{*}$} \\
\hline & Kontrol & 30 & 7,23 & 2,71 & & & \\
\hline \multirow{2}{*}{ Sayı Sembolünü Sıralama } & Deney & 30 & 2,50 & 1,61 & \multirow{2}{*}{58} & \multirow{2}{*}{2,236} & \multirow{2}{*}{$0,023^{*}$} \\
\hline & Kontrol & 30 & 3,43 & 1,48 & & & \\
\hline \multirow{2}{*}{ Rakam Yazma } & Deney & 30 & 4,60 & 2,71 & \multirow{2}{*}{58} & \multirow{2}{*}{2,608} & \multirow{2}{*}{$0,012 *$} \\
\hline & Kontrol & 30 & 6,40 & 2,63 & & & \\
\hline \multirow{2}{*}{ Toplama } & Deney & 30 & 6,00 & 3,70 & \multirow{2}{*}{58} & \multirow{2}{*}{2,014} & \multirow{2}{*}{$0,049 *$} \\
\hline & Kontrol & 30 & 7,80 & 3,20 & & & \\
\hline \multirow{2}{*}{ Çıkartma } & Deney & 30 & 5,73 & 3,99 & \multirow{2}{*}{58} & \multirow{2}{*}{3,816} & \multirow{2}{*}{$0,000^{*}$} \\
\hline & Kontrol & 30 & 9,30 & 63,21 & & & \\
\hline \multirow{2}{*}{ Sayı Kavramı Testi Toplam Puan } & Deney & 30 & 37,63 & 12,74 & \multirow{2}{*}{43,119} & \multirow{2}{*}{5,759} & $0000 *$ \\
\hline & Kontrol & 30 & 52,67 & 6,49 & & & $0,000^{\circ}$ \\
\hline$* \mathrm{p}<0,05$ & & & & & & & \\
\hline
\end{tabular}


Tablo 6 incelendiğinde deney ve kontrol grubunun ritmik sayma, rakam tanıma, birebir eşleştirme, sayı konumu, sayı sembolünü sıralama, rakam yazma, toplama, çıkartma alt boyutları ve sayı kavramı testi toplam puanı için ön test puanlarının farklılık gösterdiği görülmektedir. Grafik 1 incelendiğinde de tüm boyutlar için deney ve kontrol grubunun ön test puanları ortalamalarının farklılaştığı açıkça görülmektedir. Bu durum deney ve kontrol grubunun uygulama öncesinde benzer özellikler taşımadığını göstermektedir. Bu durumda uygulamanın etkililiğini değerlendirmek için ön test puanlarının kontrol değişkeni olarak etkisinin çıkarılarak kovaryans analizi (ANCOVA) yapılması uygun görülmesine rağmen varyansların homojenliği sağlanmadığı tespit edildiğinden analizin yapılması uygun bulunmamıştır. Bu nedenle uygulamanın etkililiğini değerlendirmek için son test puanlarından ön test puanları çıkarılarak elde edilen erişi puanları üzerinden analiz yapılmıştır.

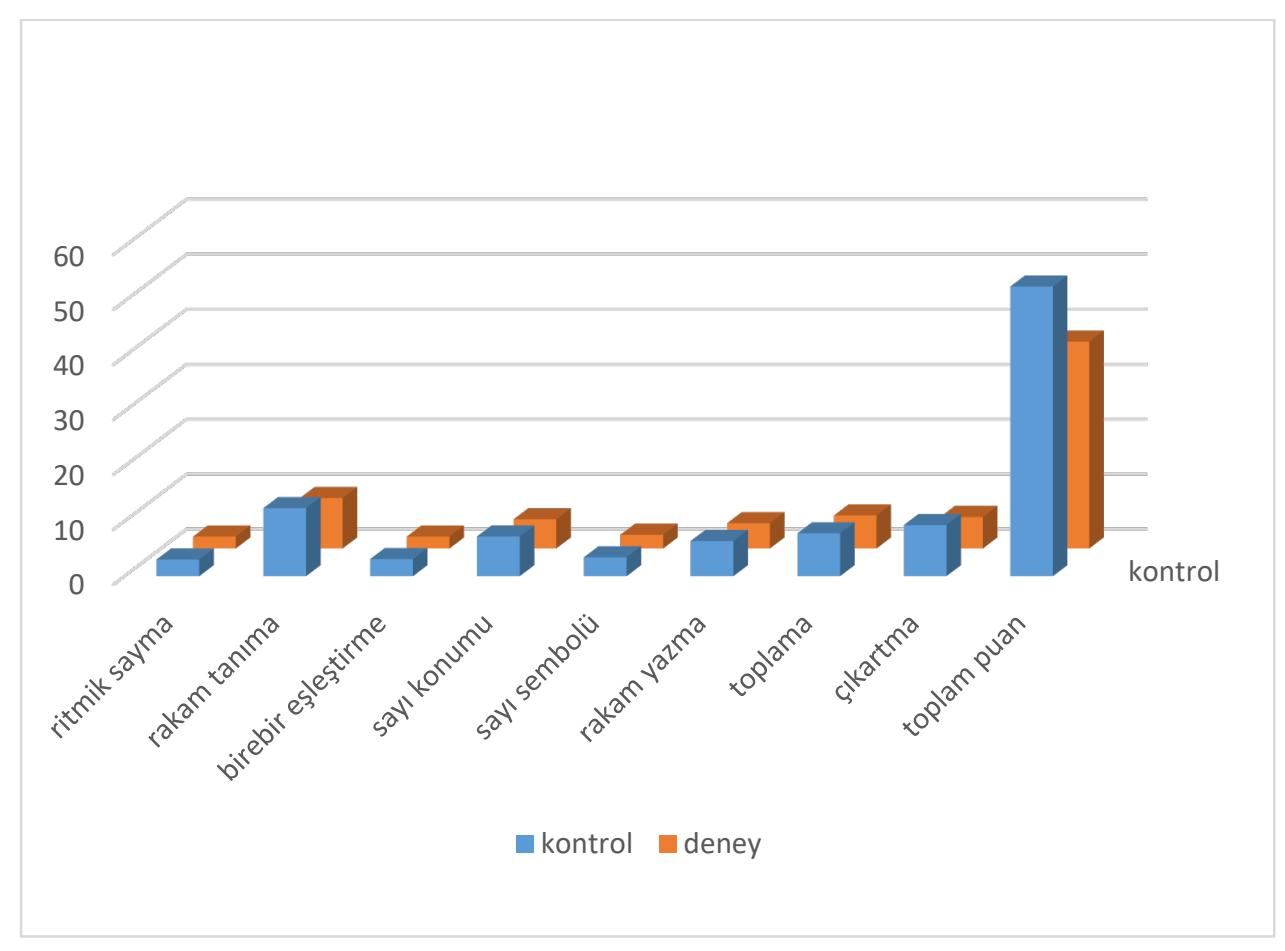

Grafik 1. Deney ve Kontrol Gruplarının Sayı Kavramı Düzeylerine İlişkin Ön Test Puanlarına Ait Ortalamalart

Deney grubundaki çocuklara uygulanan drama programının sayı kavramı gelişimi üzerindeki etkililiğini değerlendirmek için deney ve kontrol grubu erişi puanları arasındaki farkın anlamlılığını test etmek amacıyla normal dağılım varsayımı sağlanmadığı için Mann Whitney U testi kullanılmıştır. Sonuçlar Tablo 7'de sunulmuştur. 
Tablo 7. Deney ve Kontrol Gruplarının Erişi Puanlarına İlişkin Puanlarına Ait Mann Whitney U Testi Sonuçları

\begin{tabular}{|c|c|c|c|c|c|c|}
\hline & & $\mathrm{n}$ & $\begin{array}{c}\text { Sira } \\
\text { Ortalamas1 } \\
\end{array}$ & $\begin{array}{c}\text { Sira } \\
\text { Toplamı } \\
\end{array}$ & $\mathrm{Z}$ & $\mathrm{p}$ \\
\hline \multirow{2}{*}{ Ritmik Sayma } & Deney & 30 & 44,38 & 1331,50 & \multirow{2}{*}{6,309} & \multirow{2}{*}{$0,000 *$} \\
\hline & Kontrol & 30 & 16,62 & 498,50 & & \\
\hline \multirow{2}{*}{ Rakam Tanıma } & Deney & 30 & 39,18 & 1175,50 & \multirow{2}{*}{4,068} & \multirow{2}{*}{$0,000^{*}$} \\
\hline & Kontrol & 30 & 21,82 & 654,50 & & \\
\hline \multirow{2}{*}{ Birebir Eşleştirme } & Deney & 30 & 42,28 & 1268,50 & \multirow{2}{*}{5,532} & \multirow{2}{*}{$0,000^{*}$} \\
\hline & Kontrol & 30 & 18,72 & 561,50 & & \\
\hline \multirow{2}{*}{ Sayı Konumu } & Deney & 30 & 43,12 & 1293,50 & \multirow{2}{*}{5,731} & \multirow{2}{*}{$0,000^{*}$} \\
\hline & Kontrol & 30 & 17,88 & 536,50 & & \\
\hline \multirow{2}{*}{ Sayı Sembolünü Sıralama } & Deney & 30 & 42,35 & 1270,50 & \multirow{2}{*}{5,561} & \multirow{2}{*}{$0,000 *$} \\
\hline & Kontrol & 30 & 18,65 & 559,50 & & \\
\hline \multirow{2}{*}{ Rakam Yazma } & Deney & 30 & 40,77 & 1223,00 & \multirow{2}{*}{4,669} & \multirow{2}{*}{$0,000^{*}$} \\
\hline & Kontrol & 30 & 20,23 & 607,00 & & \\
\hline \multirow{2}{*}{ Toplama } & Deney & 30 & 42,97 & 1289,00 & \multirow{2}{*}{5,700} & \multirow{2}{*}{$0,000 *$} \\
\hline & Kontrol & 30 & 18,03 & 541,00 & & \\
\hline \multirow{2}{*}{ Çıkartma } & Deney & 30 & 40,78 & 1223,50 & \multirow{2}{*}{4,669} & \multirow{2}{*}{$0,000^{*}$} \\
\hline & Kontrol & 30 & 20,22 & 606,50 & & \\
\hline \multirow{2}{*}{$\begin{array}{c}\text { Sayı Kavramı Testi Toplam } \\
\text { Puan }\end{array}$} & Deney & 30 & 45,22 & 1356,50 & \multirow{2}{*}{6,536} & \multirow{2}{*}{$0,000^{*}$} \\
\hline & Kontrol & 30 & 15,78 & 473,50 & & \\
\hline
\end{tabular}

${ }^{*} \mathrm{p}<0,05$

Tablo 7'ye göre deney ve kontrol grubunun ritmik sayma, rakam tanıma, birebir eşleştirme, sayı konumu, sayı sembolünü sıralama, rakam yazma, toplama, çıkartma alt boyutları ve sayı kavramı testi toplam puanı için erişi puanlarının farklılık göstermektedir. Sıra ortalamaları incelendiğinde bu farklılığın tüm boyutlar için deney grubu lehine olduğu ortaya konulmuştur. Grafik 2 incelendiğinde de tüm boyutlar için deney grubu ortalamalarının kontrol grubundan açık bir biçimde yükssek olduğu görülmektedir. Diğer bir deyişle uygulanan yaratıcı drama programı çocukların sayı kavramının gelişmesinde etkili olmuştur. 


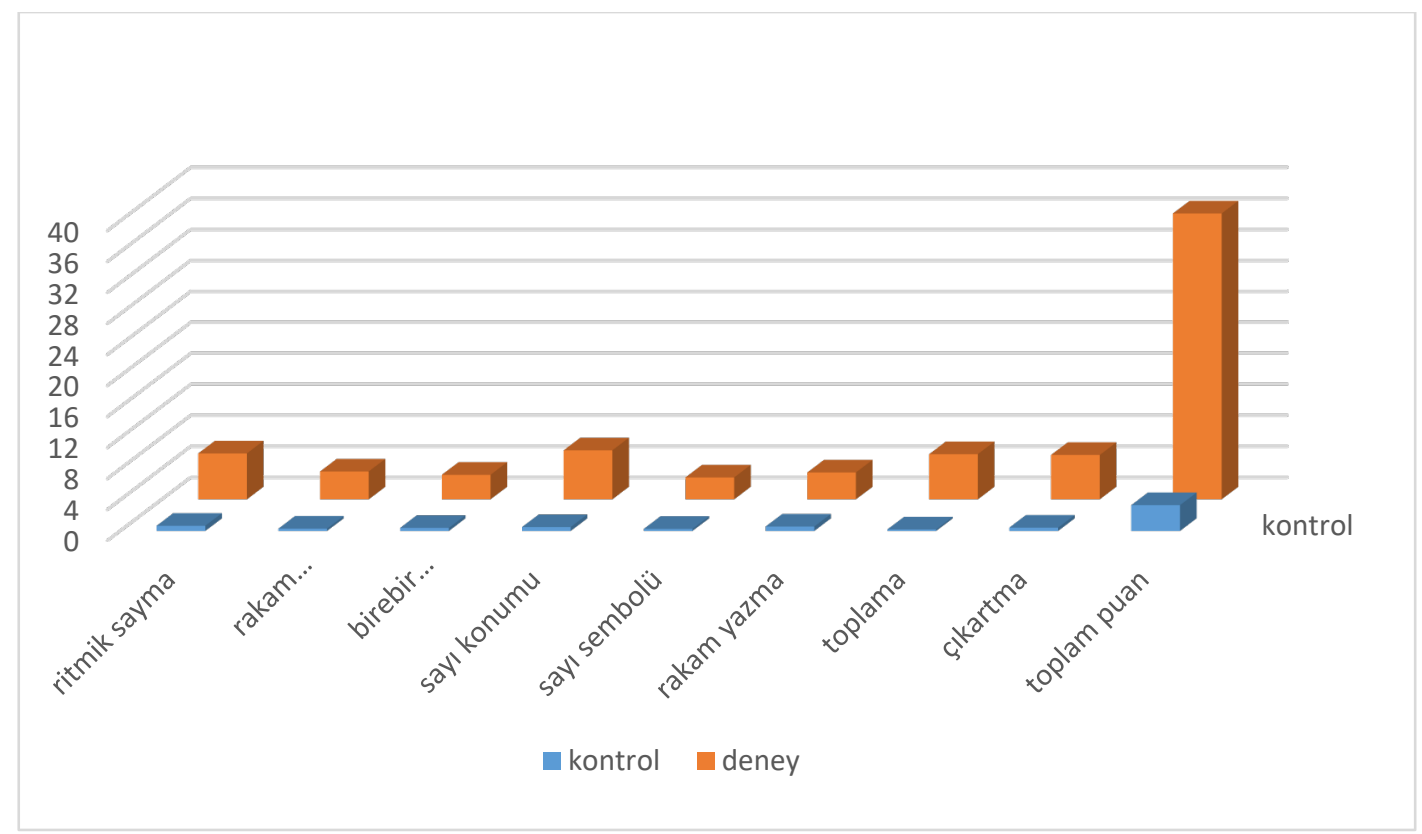

Grafik 2. Deney ve Kontrol Gruplarının Sayı Kavramı Düzeylerine Illişkin Erişi Puanlarına Ait Ortalamalart

\section{SONUÇ VE TARTIŞMA}

$\mathrm{Bu}$ çalışma 5-6 yaş çocuklarına ritmik sayma, toplama, çıkartma, eşleştirme, eksik sayı sembolünü bulma gibi sayı kavram becerilerinin kazandırılmasında drama çalışmalarının etkisini incelemeyi amaçlamaktadır. Elde edilen veriler uygun istatistiksel analizlerle değerlendirilmiş ve aşağıdaki sonuçlara ulaşılmıştır.

Deney grubundaki çocuklara uygulanan drama programının sayı kavramı gelişimi üzerindeki etkililiğini değerlendirmek için deney ve kontrol grubu puanları arasındaki farkın anlamlılığı test edilmiştir. Deney ve kontrol grubunun ritmik sayma, rakam tanıma, birebir eşleştirme, sayı konumu, sayı sembolünü sıralama, rakam yazma, toplama, çıkartma alt boyutları ve sayı kavramı testi toplam puanı için erişi puanlarının farklılık göstermektedir. Sıra ortalamaları incelendiğinde bu farklılığın tüm boyutlar için deney grubu lehine olduğu görülmektedir. Tüm boyutlar için deney grubu ortalamalarının kontrol grubundan açık bir biçimde yüksek olduğu görülmüştür. Diğer bir deyişle beş- altı yaş deney grubuna uygulanan yaratıcı drama programı çocukların sayı kavramının gelişmesinde etkili olmuştur. Bulut Pedük (2007), altı yaş grubundaki çocuklara çoklu zeka kuramına dayalı matematik eğitimi vererek çocukların matematik yeteneğine etkisini incelediği araştırmasında çocuklara sözel, görsel, müziksel, bedensel kinestetik, sosyali içsel kişisel ve doğa etkinlikleriyle matematik eğitimi vermiştir. Araştırma sonucunda çoklu zeka kuramına yönelik matematik eğitimi verilen çocukların eşleştirme, sınıflandırma, karşılaştırma, sıralama, sayı kavramı, işlem kavramı, geometrik 
şekiller, ölçme ( uzunluk, miktar, kütle, hacim, zaman) gibi matematik becerilerinin olumlu yönde etkilendiği saptanmıştır. Bu çalışma da, araştırmanın sonuçlarını destekler niteliktedir.

Drama yöntemi ile verilen matematiksel sayı kavramları çocukların öğrenmelerini kolaylaştırarak kavram kazanımını kolaylaştırmaktadır (Ürkün, 1992; Özsoy, 2003; Peterson, 2004). Benzer çalışmalar yaratıcı drama yöntemi ile verilen sayı kavramı kazandırmaya yönelik çalışmalarda çocukların matematiksel becerilerini oyun ortamıyla geliştirmeyi amaçlaması nedeniyle deney grubundaki çocukların aldıkları yüksel puanları açıklamaktadır.

Çocuklarının cinsiyetine göre sayı kavramı düzeylerinin farklılaşıp farklılaşmadığına incelemek için ilişkisiz örneklemler t-testi kullanılmış ve sonuçlar çocukların cinsiyetine göre ritmik sayma, rakam tanıma, birebir eşleştirme, sayı konumu, rakam yazma, toplama, çıkartma alt boyutları ve sayı kavramı testi toplam puanları anlamlı farklılık göstermez iken ( $p>0,05)$; sayı sembolünü sıralama alt boyutu cinsiyete göre anlamlı farklılık göstermiştir $(p<0,05)$. Sayı sembolünü sıralama alt boyutu için kız çocuklarının ortalamalarının erkek çocuklardan daha yüksek olduğu görülmüştür. Diğer bir deyişle sayı kavramının sayı sembolü sıralama alt boyutunda kız çocuklardan elde edilen veriler, erkek çocuklardan elde edilen verilere göre daha anlamlidir.

Çocuklarının yaşına göre sayı kavramı düzeylerinin farklılaşıp farklılaşmadığı incelendiğinde çocukların yaşlarına göre ritmik sayma, rakam tanıma, birebir eşleştirme, sayı konumu, sayı sembolünü sıralama, toplama, alt boyutları ve sayı kavramı testi toplam puanları anlamlı farklılık görülmezken iken ( $p>0,05$ ); rakam yazma ve çıkartma alt boyutlarında yaşa göre anlamlı farklılık dikkati çekmektedir $(\mathrm{p}<0,05)$. Sıra ortalamaları incelendiğinde rakam yazma alt boyutu için altı yaşındaki çocukların ortalamalarının beş yaş çocuklarına göre; çıkarma alt boyutu için beş yaşındaki çocukların ortalamaları altı yaş çocuklarına göre daha yüksek olduğu gözlenmiştir. Diğer bir deyişle rakam yazma becerisinde altı yaş çocuklarından elde edilen veriler daha anlamlı iken, çıkartma becerisinde beş yaş çocuklarından alınan veriler daha anlamlidir.

Güven (1997), yaptığı araştırmasında Erken Matematik Yeteneği Testi-2' nin geçerlik, güvenirlik, norm çalışması ve sosyokültürel faktörlerin matematik yeteneğine etkisinin incelemiştir. Araştırma sonucunda 3-5 yaş aralığındaki çocukların matematik yeteneği puan ortalamalarının 6-8 yaş aralığındaki çocukların ortalamalarından daha düşük olduğu saptanmiştır. 
Daha önce yapılan çalışmalar incelendiğinde yaşın artmasıyla birlikte çocukların matematiksel kavram becerilerinin de arttığg ve yaş grupları arasındaki farklılığın büyük gruplar lehine olduğu görülmüştür. Artan yaş ile bilişsel gelişimin doğru orantılı olarak ilerlemesi sonucu çocuklarda sayısal becerilerin olumlu yönde geliştiği düşünülebilir.(Cepoğlu, 1994; Güven, 1997).

Çocukların okula kaç yaşında başladıkları ve okula devam etme sürelerinin sayı kavramı ritmik sayma, rakam tanıma, birebir eşleştirme, sayı konumu, sayı sembolünü sıralama, rakam yazma, toplama, çıkartma becerilerinde anlamlı bir farklılık görülmemektedir $(p>0,05)$. Okul öncesi beş altı yaş gruplarıyla yapılan matematiksel becerilerin ve sayı kavramı kazanımına ilişkin benzer çalışmalar incelendiğinde; uygulanan eğitim programlarındaki deney gruplarının, kontrol gruplarına nazaran aldıkları eğitimler sonucu ön test ve son test puanları arasında anlamlı farkl11ıklar gözlenmiştir (Ürkün, 1992; Tarım-Gözübatık ve Deretarla-Gül, 2004; Young-Loveridge, 2004; Sezer, 2008).

İki gruplu yarı deneysel olarak tasarlanan araştırmadan elde edilen bulgulara göre, deney ve kontrol grubunun ritmik sayma, rakam tanıma, birebir eşleştirme, sayı konumu, sayı sembolünü sıralama, rakam yazma, toplama, çıkartma alt boyutları ve sayı kavramı testi toplam puanı için ön test puanlarının farklılık gösterdiği, deney ve kontrol grubunun uygulama öncesinde benzer özellikler taşımadığını saptanmıştır.

Deney ve kontrol grubunun ritmik sayma, rakam tanıma, birebir eşleştirme, sayı konumu, sayı sembolünü sıralama, rakam yazma, toplama, çıkartma alt boyutları ve sayı kavramı testi toplam puanı için erişi puanlarının farklılık gösterdiği bulunmuştur. Sıra ortalamaları incelendiğinde ise bu farklılığın tüm boyutlar için deney grubu lehine olduğu saptanmış.

\section{Öneriler}

$\mathrm{Bu}$ araştırmada; drama eğitimi ile beş-altı yaş çocuklarına sayı kavramı kazandırılması amacıyla yapılan çalışma sonucunda; drama yolu ile çocukların etkinliklere aktif katılımlarının sağlanarak, öğrenmelerinin daha kolay, etkili olduğu ve sayı kavramını kazandıkları görülmektedir. Çalışma sonucunda elde edilen bulgular da dikkate alınarak şu öneriler sunulabilir;

1. Öğretmenler sınıflarında yaratıcı dramayı destekleyen öğretim yöntemlerini kullanarak farklı drama tekniklerinin uygulanmasıyla çocuklardaki gelişimi destekleyebilirler. Yaratıcı drama programına dayalı sayı kavramı eğitimi çocuğun oyunla eğlenerek öğrenmesine imkân sağladığı gibi öğrenmeyi de kalıcı hale getirebilir. 
2. Okul öncesinde drama ile eğlenerek öğrenen çocukta matematiksel kavramlarla ilgili olumlu tutumların gelişmesi sağlanabilir. $\mathrm{Bu}$ nedenle erken çocukluk döneminde matematik becerilerini kazandırırken eğitimde drama etkinliklerine ağırlık verilmelidir.

3. Okul öncesi eğitim programlarında drama eğitimine ağırlık verilerek sayı kavramının yanı sıra diğer tüm kavramlarının kazandırılmasında da kullanılması önerilebilir.

4. Eğlenerek oyun içinde öğrenen çocuğun soyuttan somuta ilişki kurnası kolaylaşırken birçok kavram olay ve olgu öğrenimi daha rahat sağlanacaktır. Bu bağlamda öğretmenlere dramanın eğitimde kullanımına yönelik hizmet içi eğitimler verilebilir.

5. Öğretmenin çocukların gelişim seviyelerine uygun, sayı kavramı kazanımında, gelişimini destekleyici eğitim ortamları hazırlayarak sunması ile matematik çocuklar için daha keyifli ve eğlenceli hale getirilebilir.

\section{KAYNAKÇA}

Adıgüzel, Ö. (2012). Eğitimde yaratıcı drama. Ankara: Naturel Yayıncılı.

Akman, Y., Yükselen, A.İ. ve Uyanık, G. (2000). Okul öncesi dönemde matematik etkinlikleri. İstanbul: Epsilon Yayınevi.

Akyürek, S. (2004). Din ögretiminde kavram öğretimi. İstanbul: Dem Yayınları.

Arı, Meziyet. (2003). Türkiye'de erken çocukluk eğitimi ve kalitenin önemi. İçinde M. Sevinç (Ed.) Gelişim ve eğitimde yeni yaklaşımlar (s.35-37). İstanbul: Morpa Kültür Yayınları.

Arı, Meziyet. (2007). Okul öncesi dönemde fen-doğa ve matematik uygulamaları. Ankara: Kök Yayıncilik.

Bayram, E., Özgül, E., Kaplan, G., Ünal, A., Yapağılı, H., Demir, K., Morgül, M., Uğurlu, N., Tantoğlu, S., Özünel, Ş. ve Ömür, Ü. (1999). İlköğretimde drama I. Ankara: MEB Devlet Kitapları.

Baştürk, R. (2012). Deneme modelleri. İçinde A. Tanrı̈ğen (Ed.) Bilimsel araştırma yöntemleri (s.31-53). Ankara: Anı Yayınc1lık.

Benhow, C.P. \& Stanley, J.C. (1983). Sex differences in mathematical reasoning ability: more facts. Science, 222, 1029-1031.

Benhow, C.P. (1988). Sex differences in mathematical reasoning ability in intellectually talented preadolescents: Their nature, effects and possible causes. Behavioral and Brain Science, 11(2), 169-232.

Benhow, C.P. and Stanley, J.C. (1980). Sex differences in mathematical ability: Fact or artifact? Science, 120(12); 1262-1264. 
Bulut Pedük, Ş. (2007). Altı Yaş Grubundaki Çocuklara Çoklu Zeka Kuramına Dayalı Olarak Verilen Matematik Eğitiminin Matematik Yeteneğine Etkisinin Incelenmesi (Yayımlanmış Doktora Tezi) Ankara Üniversitesi, Ankara.

Çepoğlu, N.H. (1994). Sayı Kavramları Testinin Geçerlik ve Güvenirlik Çalışması (Yayımlanmamış Yüksek Lisans Tezi) Marmara Üniversitesi, İstanbul.

Dere, H. (2000). Okul Öncesi Ĕ̆itim Kurumlarına Devam Eden Altı Yaş Çocuklarına Bazı Matematik Kavramlarını Kazandırmada Yapılandırılmış ve Geleneksel Yöntemlerin Karşılaşıtırılması (Yayımlanmamış Yüksek Lisans Tezi) Gazi Üniversitesi, Ankara.

Eğitmen, A. (1999). Yaratıcı drama lideri. Çă̆daş Drama Derneği Bülteni, 2, 14-15.

Frakes, C. and Kline, K. (2000). Teaching young mathematicians : The challenges and rewards. Teaching Children Mathematics, 6 (6), 376 - 381.

Geist, E. (2001). Children are born mathematicians: Promoting the construction of early the mathematical concepts in children under five. Young Children, 56 (4), 12-18.

Genç, H. (2005). Eğitimde drama ve/ veya dramada eğitim. Kazım Karabekir Eğitim Fakültesi Dergisi, (KKEFD). 12, 99-100.

George, M. W. (1989). Developing preschool mathematical concepts, The Arithmetic Teacher, $37(4), 36-41$.

Güven, Y. (1997). Erken Matematik Yeteneği Testi-2'nin Geçerlik, Güvenirlik, Norm Çalışması ve Sosyokültürel Faktörlerin Matematik Yeteneğine Etkisinin Incelenmesi (Yayımlanmamış Doktora Tezi) Marmara Üniversitesi, İstanbul.

Güven, Y. (2000). Erken çocukluk döneminde sezgisel düşünme ve matematik. İstanbul: Ya-Pa Yayınlar1.

İrköcü, S. (2006). Okul Öncesi Eğitim Kurumuna Devam Eden Altı Yaşındaki Çocuklara Uygulanan Ev Odakl Matematiksel Destek Programının Çocukların Matematiksel Kavram Edinimine Etkisinin İncelenmesi (Yayımlanmamış Yüksek Lisans Tezi) Gazi Üniversitesi, Ankara.

Jacobson, L. (2001). Experts say young children need more math. Education Week, 21(4), 3-5.

Kandır, A., \& Orçan, M. (2010). Okul öncesi dönemde matematik ĕgitimi. İstanbul: Morpa Yayınları.

Kaptan, F. (1998). Fen öğretiminde kavram haritası yönteminin kullanılması. Hacettepe Üniversitesi Eğitim Fakültesi Dergisi, 14, 95-99.

Karasar, N. (2014). Bilimsel araştırma yöntemi. Ankara: Nobel Yayın Dağıtım.

Karataş, Ş. (1996). Özel ve Resmi Anaokullarına Devam Eden 5-6 yaş Grubundaki Çocukların Bazı Sayı Kavramlarına Ait Becerilerinin Incelenmesi (Yayımlanmamış Yüksek Lisans Tezi) Hacettepe Üniversitesi, Ankara.

Klausmeier, H.J. (1992). Concept learning and concept teaching. Educational Psychologist, $27(3), 262-286$.

Kritou, Despo., Eteokleous, Nikleia.,ve Gregoriou, George. (2005). Preschoolers developing mathematical understveing through computer-based activities. Eurocaon, 27, 788-791.

Koç, F. (1999). Yaratıcı Dramanın Öğrenmeye Etkisi Sosyal Bilimler Öğretiminde Bir Yöntem Olarak Kullanılması (Yayımlanmamış Yüksek Lisans Tezi) Ankara Üniversitesi, Ankara. 
Kurtuluş, E. (1999). Okul Öncesi Eğitim Kurumuna Devam Eden 5-6 Yaş Grubu Çocuklarına Yaratıcı Etkinlikler Yoluyla Kavram (Zaman Kavramı) Öğretilmesi (Yayınlanmamış Yüksek Lisans Tezi) Marmara Üniversitesi, İstanbul.

Küçükturan, G., Eyidoğan, F. (2004). Okul öncesi dönemde bitki kavramının oluşumu. İstanbul: Ya-Pa Yayınları.

Lovell, K. (1971). The growth of understanding in mathematics: Kindergarten through grade three. USA, Rinehart and Winston.

Metin, N. (1992). Okul öncesi dönemdeki çocuklarda matematik kavramların gelişimi. Ya-Pa 8. Okul Öncesi Eğitimi ve Yaygınlaştırılması Semineri. İstanbul: Yapa Yayınları.

Özsoy, N. (2003). İlköğretim matematik derslerinde yaratıcı drama yönteminin kullanılması. Balıkesir Üniversitesi Fen Bilimleri Enstitüsü Dergisi, 5(2), 112-119.

Peterson, I. (2004). Drama in numbers.

http://www.sciencenews.org/20021221/bob8 adresinden alınmıştır.

Sağlam, T. (2004). Dramatik eğitim amaç mı araç mı?. Tiyatro Araştırmaları Dergisi, (17), 422.

San, İ. (1996). Yaratıcılığı geliştiren bir yöntem ve yaratıcı bireyi yetiştiren bir disiplin; eğitsel yaratıcı drama. Yeni Türkiye Dergisi, 2(7), 148-161.

Sezer, T. (2008). Okul Öncesi Ĕgitimi Alan Beş Yaş Grubu Çocuklara Sayı ve İşlem Kavramlarını Kazandırmada Drama Yönteminin Etkisinin Incelenmesi (Yayımlanmamış Yüksek Lisans Tezi) Abant İzzet Baysal Üniversitesi, Bolu.

Sucuoğlu, B., Büyüköztürk, Ş., Ünsal, P. (2008). Türk çocuklarının temel-ilişkisel kavram bilgilerinin değerlendirilmesi. (10.09.2017). Illkögretim online.; 7(1), 203-217. Web: http://ilkogretim-online.org.tr. Adresinden alınmıştır.

Şentürk, N. (1996). Eğitimde yaratıcı drama. Çă̆daş Eğitim Dergisi, 21(23), 23-25.

Şimşek, A. (2006). Kavramların Öğretimi. İçerik Türlerine Dayalı Öğretim. Ankara: Nobel Yayın Dağıtım.

Tarım-Gözübatık, K. ve Deretarla Gül, E. (2004). Anasınıfı ve ilköğretim birinci sınıf çocuklarının toplama ve çıkarma becerilerinde kullandıkları stratejilerin incelenmesi. OMEP Dünya Konsey Toplantısı ve Konferans1, Bildiriler Kitabı. 2, 270-283. Kuşadası.

Uyanık, Ö., \& Kandır, A. (2010). Okul öncesi dönemde erken akademik beceriler. Kuramsal Ĕ̈itimbilim Dergisi, 3(2), 118-134.

Ülgen, G. (2004). Kavram geliştirme kuramlar ve uygulamalar. Ankara: Nobel Yayın Dağıtım.

Ürkün, M. (1992). Okulöncesi Dönemde 4-5 Yaşındaki Çocuklara Uygulanan Matematiksel Kavramlara Dayalı Destekleyici Ĕgitim Modelinin Yaş ve Cinsiyete Göre Etkisinin Incelenmesi (Yayımlanmamış Yüksek Lisans Tezi) Ankara Üniversitesi, Ankara.

Üstündağ, T. (1996). Yaratıcı dramanın üç boyutu. Yaşadıkça Eğitim Dergisi, 49, 19-23.

Wolfgang, H. C., Stannard, L. L., and Jones, I. (2003). Advanced constructional play with legos among preschoolers as a predictor of later school achievement in mathematics, Early Child Development and Care, 173(5), 467-475.

Wortham, C. S. (1998). Early childhood curriculum, developmental bases for learning and teaching. Second Edition. USA, Prentice Hall. 
Wortham, C. S. (2006). Early childhood curriculum, developmental bases for learning and teaching. New Jersey, Pearson/ Merrill/Prentice Hall.

Yıldız, V. (1999). Okulöncesinde matematik eğitimi, işbirlikli öğrenme ve geleneksel öğretimin okulöncesi çocuklarının temel matematik becerilerinin gelişimi üzerine etkisi. Ĕgitim ve Bilim Dergisi, 23(11), 42 -50.

Young-Loveridge, M.J. (2004). Effects on early numeracy of a program using number books and games. Early Childhood Research Quarterly, 19(1), 82-92.

Zhou, Xin., ve Wang, Bin. (2004). Preschool children's resresentation and understanding of written number symbols. Early Child Development and Care, 174(3), 253-266. 